\title{
The multimodal concept of hemodynamic stabilization
}

\author{
Krisztián Tánczos, Márton Németh and Zsolt Molnár * \\ Department of Anaesthesiology and Intensive Therapy, University of Szeged, Szeged, Hungary
}

\section{Edited by:}

Evangelos Giamarellos-Bourboulis, University of Athens, Greece

Reviewed by:

Linda Johansson, Karolinska

Institutet, Sweden

Peter Pickkers, Radboud University

Medical Centre, Netherlands

George Dimopoulos, University

Hospital Attikon, Greece

\section{*Correspondence:}

Zsolt Molnár, Department of

Anaesthesiology and Intensive

Therapy, University of Szeged, 6

Semme/weis Street, Szeged 6725,

Hungary

e-mail:zsoltmolna@gmail.com
Hemodynamic instability often leads to hypoperfusion, which has a significant impact on outcome in both medical and surgical patients. Measures to detect and treat tissue hypoperfusion early by correcting the imbalance between oxygen delivery and consumption is of particular importance. There are several studies targeting different hemodynamic endpoints in order to investigate the effects of goal-directed therapy on outcome. A so-called multimodal concept putting several variables in context follows simple logic and may provide a broader picture. Furthermore, rather than treating population based "normal" values of certain indices, this concept can be translated into the individualized patient care to reach adequate oxygen supply and tissue oxygenation in order to avoid under, or over resuscitation, which are equally harmful. The purpose of this review is to give an overview of current data providing the basis of this a multimodal, individualized approach of hemodynamic monitoring and treatment.

Keywords: hemodynamic optimization, cardiac output, stroke volume, central venous oxygen saturation, venous to arterial carbon dioxide gap

\section{INTRODUCTION}

Development of multiorgan disorders is often the result of hypoperfusion, which severely affects outcome of medical and surgical patients alike and substantially increases the utilization of resources and costs (1). Therefore, the use of early and efficient therapeutic strategies able to detect tissue hypoperfusion and to treat the imbalance between oxygen consumption and delivery is of particular importance (2). Traditional endpoints such as heart rate, blood pressure, mental status, and urine output can be useful in the initial identification of inadequate perfusion, but are limited in their ability to identify ongoing, compensated shock (3). Therefore, more detailed assessment of global macrohemodynamic indices such as cardiac output (CO) and derived variables and measures of oxygen delivery and uptake, may be necessary to guide treatment $(4,5)$. Furthermore, after the optimization of these parameters, indicators of tissue perfusion should also be assessed to verify the effectiveness of therapy (6).

\section{PHYSIOLOGICAL ISSUES}

The primary goal of the cardiorespiratory system is to deliver adequate oxygen to the tissues to meet their metabolic requirements. The adequacy of tissue oxygenation is determined by the balance between the rate of oxygen transport to the tissues (oxygen delivery, $\mathrm{DO}_{2}$ ) and the rate at which the oxygen is used by the tissues (oxygen consumption, $\mathrm{VO}_{2}$ ) (7). The standard formulas to determine oxygen delivery and oxygen consumption is shown in Figure 1.

In the critically ill and in the perioperative period, there is often an imbalance between delivery and consumption. Oxygen delivery can be inadequate if arterial oxygen content $\left(\mathrm{CaO}_{2}\right)$ and/or $\mathrm{CO}$ is reduced $(8,9)$. The circulation can compensate to some extent, and $\mathrm{VO}_{2}$ is usually independent in a wide range of $\mathrm{DO}_{2}$. However, beyond a critical point any further drop in $\mathrm{DO}_{2}$ will inevitably result in a decrease in $\mathrm{VO}_{2}$. In other words, after exhausting compensatory resources $\mathrm{VO}_{2}$ becomes dependent on $\mathrm{DO}_{2}$ and aerobic metabolism will have to be switched to anaerobic metabolism, leading to metabolic acidosis and oxygen debt (10).

The principle task of acute care is to avoid or correct oxygen debt by optimization of the oxygen supply and consumption. Furthermore, it is just as important to recognize that $\mathrm{DO}_{2}$ and tissue perfusion has normalized, therefore any further measures to increase $\mathrm{DO}_{2}$ may do harm by unnecessary over resuscitation.

There is also mounting evidence that conventional parameters such as blood pressure, central venous pressure, heart rate are poor indicators of cardiac index or oxygen delivery $(11,12)$, and there is also increasing evidence that, for example, in high-risk surgery perioperative care algorithms based on advanced hemodynamic monitoring are beneficial $(13,14)$.

\section{GOAL-DIRECTED CONCEPT IN HEMODYNAMIC MONITORING}

The multimodal concept in hemodynamic monitoring can be translated into the individualized use of target endpoints for hemodynamic stabilization instead of treating "normal" values, and can help to reach adequate oxygen supply and tissue oxygenation in order to avoid under or over resuscitation, which are equally harmful. It is important to note, that so-called "normal" values may be true for a population, but may be false for an individual patient.

\section{CARDIAC OUTPUT AND DO ${ }_{2}$ AS RESUSCITATION ENDPOINTS}

Several clinical investigations were performed on $\mathrm{CO}$ and derived variables based goals directed hemodynamic support in high-risk surgery. In two recent meta-analyses, it was found that cardiac index and $\mathrm{DO}_{2}$ guided treatment resulted in reduced mortality as compared to high-risk surgical patients receiving standard therapy $(13,14)$. 


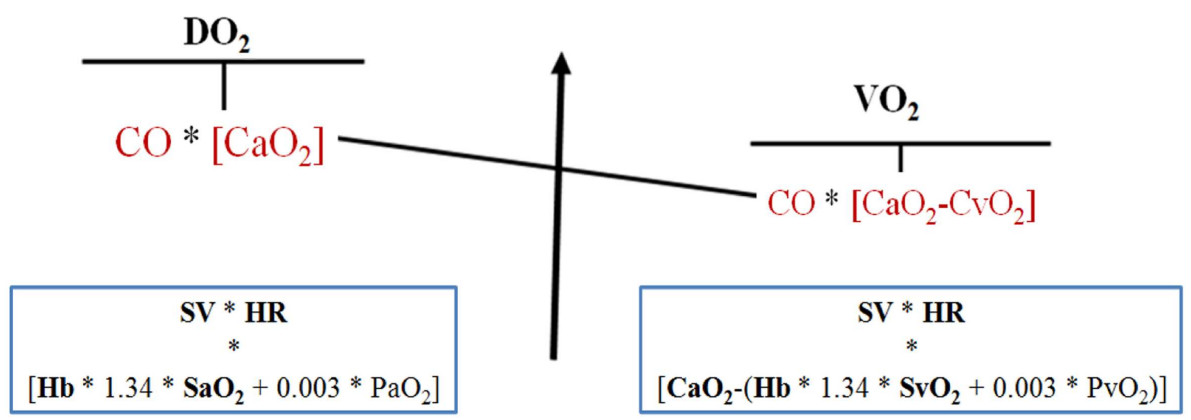

FIGURE 1 | Oxygen delivery and consumption. $\mathrm{DO}_{2}$, oxygen delivery; SV, stroke volume; $\mathrm{HR}$, heart rate; $\mathrm{Hb}$, hemoglobin; $\mathrm{SaO}_{2}$, hemoglobin arterial oxygen saturation; $\mathrm{PaO}_{2}$, arterial oxygen partial pressure; $\mathrm{CO}$, cardiac output;
$\mathrm{CaO}_{2}$, arterial oxygen content, $\mathrm{VO}_{2}$; oxygen consumption, $\mathrm{SvO}_{2}$; hemoglobin mixed venous oxygen saturation; $\mathrm{PvO}_{2}$, venous oxygen partial pressure; $\mathrm{CvO}_{2}$, venous oxygen content.

\section{STROKE VOLUME VARIATION AND PULSE PRESSURE VARIATION AS RESUSCITATION ENDPOINTS}

Recently, less invasive devices assessing $\mathrm{CO}$ by pulse contour analysis based on the radial artery pressure signal have been introduced. Although these devices show lower precision compared to the gold standards of thermodilution, there is some evidence that these methods can adequately show changes and trends in the hemodynamic status (15). As pulse pressure variation and stroke volume variation are well established indicators of fluid responsiveness, these devices seem to be simple and useful alternatives to invasive hemodynamic monitoring (16). Furthermore, in recent studies fluid therapy guided by SVV and PPV proved to be more accurate than static preload indicators-based approaches and has also been shown to improve patient outcome, by reducing postoperative complication rate significantly $(17,18)$. However, pulse pressure variation and stroke volume variation are limited to patients who receive controlled mechanical ventilation with normal sinus rhythm $(19,20)$.

\section{VENOUS TO ARTERIAL $\mathrm{CO}_{2}$ GAP AS THERAPEUTIC ENDPOINT}

Another easily obtainable blood flow related blood gas parameter is the central venous to arterial carbon dioxide gap $\left(\mathrm{dCO}_{2}\right)$. Several authors have reported increased $\mathrm{dCO}_{2}$ in different low flow states (21-23). In oxygen debt caused anaerobic metabolism, hydrogen ions are generated in two ways: (1) hydrolysis of adenosine triphosphate to adenosine diphosphate and (2) increased production of lactic acid (24). Hydrogen ions are buffered by bicarbonate presented in the cells, and this process will generate $\mathrm{CO}_{2}$ production (25). While arterial $\mathrm{PaCO}_{2}$ is variable and dependent on pulmonary gas exchange, central venous $\mathrm{PvCO}_{2}$ is dependent on the capability of the flow (i.e., CO) to wash out carbon dioxide from the tissues. The Fick principle adapted to carbon dioxide demonstrates the inverse relationship between the $\mathrm{CO}$ and $\mathrm{dCO}_{2}$ (26). This postulate that increased $\mathrm{dCO}_{2}$ reflects decreased flow was confirmed in several critically ill conditions such as severe sepsis, heart failure, and severe hypovolemia $(27,28)$. Furthermore, adding the $\mathrm{dCO}_{2}$ to $\mathrm{ScvO}_{2}$ for identifying $\mathrm{VO}_{2} / \mathrm{DO}_{2}>30 \%$, there was an improvement in specificity, positive predictive, and negative predictive values (29).
In cases like severe sepsis, when oxygen uptake is insufficient due to microcirculatory and/or mitochondrial defects, $\mathrm{ScvO}_{2}$ may be elevated (i.e., false negative). Previous studies have suggested that under such circumstances the increased value of $\mathrm{dCO}_{2}$ (>5 mmHg), may help the clinician in detecting inadequate $\mathrm{DO}_{2}$ to tissues, hence the complementary use of $\mathrm{ScvO}_{2}$ and $\mathrm{dCO}_{2}$ is recommended (30-32).

\section{MEASURES OF OXYGEN DELIVERY AND EXTRACTION}

Perhaps the most commonly used methods to assess global $\mathrm{VO}_{2} / \mathrm{DO}_{2}$ are mixed venous oxygen saturation $\left(\mathrm{SvO}_{2}\right)$ and its surrogate $\mathrm{ScvO}_{2}$. Central venous oxygen saturation is an easily obtained parameter via a central venous catheter already in situ in most critically ill patients and it is often used as a marker of the balance between oxygen delivery and consumption. Because of the different positions of the pulmonary artery and central venous catheters (entire body in the case of $\mathrm{SvO}_{2}$ versus brain and the upper part of the body in the case of $\mathrm{ScvO}_{2}$ ) there has been a considerable debate on the interpretation of $\mathrm{ScvO}_{2}$ values as compared to $\mathrm{SvO}_{2}$. Most of the studies that have analyzed the relationship between $\mathrm{ScvO}_{2}$ and $\mathrm{SvO}_{2}$ have shown that $\mathrm{ScvO}_{2}$ is on an average $5 \%$ higher than $\mathrm{SvO}_{2}$ and is considered as a reasonable surrogate marker in the clinical setting (33-35). However, recent clinical trials, mainly on septic patients, were unable to show satisfactory agreement between $\mathrm{ScvO}_{2}$ and $\mathrm{SvO}_{2}$. This could in part be explained by modifications of blood flow distribution and oxygen extraction by brain and splanchnic tissues (36). It seems that $\mathrm{ScvO}_{2}$ and $\mathrm{SvO}_{2}$ are not numerically equivalent but the changes usually occur in a parallel manner (37).

The main factors, which influence $\mathrm{ScvO}_{2}$, are hemoglobin, arterial oxygen saturation of hemoglobin, $\mathrm{CO}$, and oxygen consumption. Theoretically if three of these factors are kept constant, the value of $\mathrm{ScvO}_{2}$ reflects the changes of the latter. There are multiple physiologic, pathologic, and therapeutic factors, which influence venous oxygen saturation, such as anemia, hypovolemia, contractility, bleeding, sedation, fever, pain, etc. (38).

One of the important features of venous saturation is that it can be pathologic both when it is high and when it is low. In a recent large cohort of septic patients in the emergency department, it 
was found that mortality was $40 \%$ in patients admitted with an $\mathrm{ScvO}_{2}<70 \%$ but in patients with an initial $\mathrm{ScvO}_{2}$ of $>90 \%$, it was almost as high $34 \%$. The latter was probably due to impaired oxygen utilization (39). High $\mathrm{ScvO}_{2}$ values may thus represent an inability of the cells to extract oxygen or microcirculatory shunting in sepsis (40). Therefore, additional measures are necessary to help evaluating high $\mathrm{ScvO}_{2}$ values, such as for example lactate, central venous to arterial $\mathrm{dCO}_{2}$, and by applying advanced invasive hemodynamic monitoring.

Lactate, the end product on anaerobic metabolism, has been thoroughly investigated over the last decades in critical care. It has good prognostic value in several clinical scenarios such as trauma, sepsis, and high-risk surgical patients (41). Not just the absolute value, but its change over time (kinetics: determined by production and clearance) seems an even better marker of adequate resuscitation and outcome (42). A lactate decrease by $20 \%$ or more per $2 \mathrm{~h}$ in the initial resuscitation of critically ill patients resulted shorter length of stay in the intensive care unit and a lower mortality rate when adjusted to predefined risk factors (43). However, if lactate kinetics is assessed every $2-6 \mathrm{~h}$, which can be regarded as far too long considering that acute resuscitation should be corrected as soon as possible, it seems that lactate kinetics rather than absolute values should be followed as resuscitation endpoints. In cases, when lactate production or elimination is impaired, the evaluation of lactate clearance is difficult to interpret. These pathological circumstances can be liver failure (44) or seizures (45).

\section{PPV, $\mathrm{dCO}_{2}$, AND STROKE VOLUME GUIDED FLUID RESUSCITATION}

In a recent animal experiment, we tested the effect of stroke volume guided hemorrhage and fluid resuscitation (46). After baseline measurements $\left(T_{\text {bsl }}\right)$, animals were bled until stroke volume index dropped by $50 \%$, then measurements were repeated $\left(T_{0}\right)$. Thereafter animals were resuscitated with lactated Ringer's solution until baseline SVI values were reached, then final measurements were recorded ( $\left.T_{\text {end }}\right)$. After bleeding, the SVI decreased by the planned $50 \%$ at $T_{0}$ and returned to its initial value by $T_{\text {end }}$ (Table 1). The CI also decreased after bleeding and reached a higher value by $T_{\text {end }}$ as compared to $T_{\text {bsl }}$. Pulse contour analysis driven SVV and PPV increased from $T_{\text {bsl }}$ to $T_{0}$ and normalized by $T_{\text {end }}$. $\mathrm{ScvO}_{2}$ decreased from $T_{\text {bsl }}$ to $T_{0}$ and although increased by $T_{\text {end }}$, it remained lower, with a mean difference of $5 \%$ as compared to $T_{\text {bsl }}$.

In these experiments, $\mathrm{ScvO}_{2}$ and $\mathrm{dCO}_{2}$ correlated well with changes in stroke volume. If the hemodynamic instability is corrected, stroke volume, $\mathrm{PPV}, \mathrm{SVV}$, and $\mathrm{dCO}_{2}$ are in the physiological range, the low $\mathrm{ScvO}_{2}$ can indicate a low hemoglobin level due to low oxygen delivery. These data also confirm that more parameters should be taken into account during resuscitation.

\section{CONCLUSION}

Early and adequate hemodynamic stabilization of the critically ill has a significant effect on outcome. Rather than following certain numbers in protocols or algorithms, a multimodal approach, of assessing hemodynamic variables together with the balance between oxygen delivery and consumption, may help to get a detailed picture about the hemodynamic status of our patients and also gives a chance for individualized treatment. The latter
Table 1 | Hemodynamic and blood gas changes during stroke volume based fluid resuscitation.

\begin{tabular}{lccc}
\hline & $\boldsymbol{T}_{\text {bsl }}$ & $\boldsymbol{T}_{\mathbf{0}}$ & $\boldsymbol{T}_{\text {end }}$ \\
\hline $\begin{array}{l}\text { Stroke volume index } \\
\left(\mathrm{mL} / \mathrm{m}^{2}\right)\end{array}$ & $26.8 \pm 4.7$ & $13.4 \pm 2.3^{*}$ & $26.6 \pm 4.1^{\#}$ \\
$\begin{array}{l}\text { Cardiac index } \\
\left(\mathrm{L} / \mathrm{min} / \mathrm{m}^{2}\right)\end{array}$ & $2.6 \pm 0.4$ & $1.8 \pm 0.3^{*}$ & $2.9 \pm 0.5^{*, \#}$ \\
$\begin{array}{l}\text { Stroke volume } \\
\text { variation (\%) }\end{array}$ & $13.6 \pm 4.3$ & $22.6 \pm 5.6^{*}$ & $12.2 \pm 4.3^{\#}$ \\
$\begin{array}{l}\text { Pulse pressure } \\
\text { variation (\%) }\end{array}$ & $13.0 \pm 4.5$ & $24.5 \pm 7.6^{*}$ & $13 \pm 4.2^{\#}$ \\
$\begin{array}{l}\text { Venous to arterial } \\
\text { carbon dioxide gap } \\
\text { (mmHg) }\end{array}$ & $5.3 \pm 2$ & $9.6 \pm 2.3^{*}$ & $5.1 \pm 2.6^{\#}$ \\
& & &
\end{tabular}

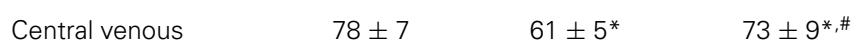

oxygen saturation (\%)

Hemoglobin $(\mathrm{g} / \mathrm{dL}) \quad 12.05 \pm 1.37 \quad 11.22 \pm 1.39 * \quad 8.45 \pm 1.1^{*}, \#$

Data are expressed as mean $\pm S D ;{ }^{*} p<0.05$ significantly different from $T_{b s l}$; $\# p<0.05$ significantly different from $T_{0}$.

$T_{0}$, baseline measurements; $T_{1}$, measurements following the hemorrhage; $T_{\text {end, }}$ measurements after the resuscitation. Data are presented as mean $\pm S D$, statistically significant difference was considered $p<0.05$.

* Significantly different from $T_{0}$.

"Significantly different from $T_{\text {end }}$.

means that the evidence, which proved beneficial for a population in clinical studies gives the frame what we fine tune for the patient's individual needs reflected by changes in this complex picture of physiology. Despite that this multimodal approach follows simple logic, it has currently not been completely proven, which renders the need for further clinical trials.

\section{REFERENCES}

1. Shoemaker WC, Appel PL, Kram HB. Role of oxygen debt in the development of organ failure sepsis, and death in high-risk surgical patients. Chest (1992) 102:208-15. doi:10.1378/chest.102.1.208

2. Shoemaker WC, Appel PL, Kram HB. Tissue oxygen debt as determinant of lethal and nonlethal postoperative organ failure. Crit Care Med (1988) 16:1117-20. doi:10.1097/00003246-198811000-00007

3. Goodrich C. Endpoints of resuscitation: what should we be monitoring? AACN Adv Crit Care (2006) 17(3):306-16. doi:10.1097/01256961-200607000-00010

4. Donati A, Pelaia P, Pietropaoli P, Preiser JC. Do use ScvO2 and O2ER as therapeutical goals. Minerva Anestesiol (2011) 77:483-4.

5. Marik PE, Desai H. Goal directed fluid therapy. Curr Pharm Des (2012) 18:6215-24. doi:10.2174/138161212803832399

6. Benes J, Pradl R, Chyrta I. Perioperative hemodynamic optimization: a way to individual goals. In: Vincent JL, editor. Annual Update in Intensive Care and Emergency Medicine 2012. New York: Springer (2012). p. 357-67.

7. Vallet B, Tavernier B, Lund N. Assessment of tissue oxygenation in the critically ill. Eur J Anaesthesiol (2000) 17:221-9. doi:10.1097/00003643-200004000-00003

8. Perner A. Diagnosing hypovolemia in the critically ill. Crit Care Med (2009) 37:2674-5. doi:10.1097/CCM.0b013e3181ad77d8

9. Sakr Y, Dubois MJ, De Backer D, Creteur J, Vincent JL. Persistent microcirculatory alterations are associated with organ failure and death in patients with septic shock. Crit Care Med (2004) 32(9):1825-31. doi:10.1097/01.CCM.0000138558. $16257.3 \mathrm{~F}$ 
10. Vincent JL. The relationship between oxygen demand, oxygen uptake, and oxygen supply. Intensive Care Med (1990) 16(Suppl 2):145-8. doi:10.1007/ BF01785244

11. Marik PE, Baram M, Vahid B. Does central venous pressure predict fluid responsiveness? A systematic review of the literature and the tale of seven mares. Chest (2008) 134:172-8. doi:10.1378/chest.07-2331

12. Osman D, Ridel C, Ray P, Monnet X, Anguel N, Richard C, et al. Cardiac filling pressures are not appropriate to predict hemodynamic response to volume challenge. Crit Care Med (2007) 35:64-8. doi:10.1097/01.CCM.0000249851. 94101.4F

13. Kern JW, Shoemaker WC. Meta-analysis of hemodynamic optimization in high-risk patients. Crit Care Med (2002) 30:1686-92. doi:10.1097/00003246200208000-00002

14. Gurgel ST, do Nascimento P Jr. Maintaining tissue perfusion in high-risk surgical patients: a systematic review of randomized clinical trials. Anesth Analg (2011) 112:1384-91. doi:10.1213/ANE.0b013e3182055384

15. Michard F, Teboul JL. Using heart-lung interactions to assess fluid responsiveness during mechanical ventilation. Crit Care (2000) 4(5):282-9. doi:10.1186/cc710

16. Marik PE, Cavallazzi R, Vasu T, Hirani A. Dynamic changes in arterial waveform derived variables and fluid responsiveness in mechanically ventilated patients: a systematic review of the literature. Crit Care Med (2009) 37:2642-7. doi:10.1097/CCM.0b013e3181a590da

17. Salzwedel C, Puig J, Carstens A, Bein B, Molnar Z, Kiss K, et al. Perioperative goal-directed hemodynamic therapy based on radial arterial pulse pressure variation and continuous cardiac index trending reduces postoperative complications after major abdominal surgery: a multi-center, prospective, randomized study. Crit Care (2013) 17:R191. doi:10.1186/cc12885

18. Lopes MR, Oliveira MA, Pereira VO, Lemos IP, Auler JO Jr, Michard F. Goaldirected fluid management based on pulse pressure variation monitoring during high-risk surgery: a pilot randomized controlled trial. Crit Care (2007) 11:R100. doi:10.1186/cc6117

19. Michard F, Teboul JL. Predicting fluid responsiveness in ICU patients: a critical analysis of the evidence. Chest (2002) 121:2000-8. doi:10.1378/chest. 121.6.2000

20. Monnet X, Osman D, Ridel C, Lamia B, Richard C, Teboul JL. Predicting volume responsiveness by using the end-expiratory occlusion in mechanically ventilated intensive care unit patients. Crit Care Med (2009) 37:951-6. doi:10.1097/CCM.0b013e3181968fe1

21. Grundler W, Weil MH, Rackow EC. Arteriovenous carbon dioxide and pH gradients during cardiac arrest. Circulation (1986) 74:1071-4. doi:10.1161/01.CIR. 74.5.1071

22. Cuschieri J, Rivers EP, Donnino MW, Katilius M, Jacobsen G, Nguyen HB, et al. Central venous-arterial carbon dioxide difference as an indicator of cardiac index. Intensive Care Med (2005) 31:818-22. doi:10.1007/s00134-005-2602-8

23. Benjamin E, Paluch TA, Berger SR, Premus G, Wu C, Iberti TJ. Venous hypercarbia in canine hemorrhagic shock. Crit Care Med (1987) 15:516-8. doi:10.1097/00003246-198705000-00013

24. Weil MH. Difference in acid-base state between venous and arterial blood during cardiopulmonary resuscitation. N Engl J Med (1986) 315:1616-8. doi:10.1056/NEJM198612183152519

25. Vallet B, Teboul JL, Cain S, Curtis S. Venoarterial CO2 difference during regional ischemic or hypoxic hypoxia. J Appl Physiol (2000) 89:1317-21.

26. Lamia B, Monnet X, Teboul JL. Meaning of arterio-venous PCO2 difference in circulatory shock. Minerva Anestesiol (2006) 72:597-604.

27. Mecher CE, Rackow EC, Astiz ME, Weil MH. Venous hypercarbia associated with severe sepsis and systemic hypoperfusion. Crit Care Med (1990) 18:585-9. doi:10.1097/00003246-199006000-00001

28. Adrogué HJ, Rashad MN, Gorin AB, Yacoub J, Madias NE. Assessing acid-base status in circulatory failure. Differences between arterial and central venous blood. N Engl J Med (1989) 320:1312-6. doi:10.1056/NEJM198905183202004

29. Kocsi S, Demeter G, Erces D, Nagy E, Kaszaki J, Molnar Z. Central venousto-arterial CO2 gap is a useful parameter in monitoring hypovolemia-caused altered oxygen balance: animal study. Crit Care Res Pract (2013) 2013:583598. doi: $10.1155 / 2013 / 583598$

30. Vallée F, Vallet B, Mathe O, Parraguette J, Mari A, Silva S, et al. Central venous-to-arterial carbon dioxide difference: an additional target for goaldirected therapy in septic shock? Intensive Care Med (2006) 34:2218-25. doi:10.1007/s00134-008-1199-0
31. Futier E, Robin E, Jabaudon M, Guerin R, Petit A, Bazin JE, et al. Central venous $\mathrm{O} 2$ saturation and venous-to-arterial $\mathrm{CO} 2$ difference as complementary tools for goal-directed therapy during high-risk surgery. Crit Care (2010) 14:R193. doi:10.1186/cc9310

32. Vallet B, Lebuffe G. How to titrate vasopressors against fluid loading in septic shock. Adv Sepsis (2007) 6:34-40.

33. Chawla LS, Zia H, Gutierrez G, Katz NM, Seneff MG, Shah M. Lack of equivalence between central and mixed venous oxygen saturation. Chest (2004) 126:1891-6. doi:10.1378/chest.126.6.1891

34. Reinhart K, Kuhn HJ, Hartog C, Bredle DL. Continuous central venous and pulmonary artery oxygen saturation monitoring in the critically ill. Intensive Care Med (2004) 30:1572-8. doi:10.1007/s00134-004-2337-y

35. Varpula M, Karlsson S, Ruokonen E, Pettilä V. Mixed venous oxygen saturation cannot be estimated by central venous oxygen saturation in septic shock. Intensive Care Med (2006) 32:1336-43. doi:10.1007/s00134-006-0270-y

36. van Beest PA, van Ingen J, Boerma EC, Holman ND, Groen H, Koopmans M, et al. No agreement of mixed venous and central venous saturation in sepsis, independent of sepsis origin. Crit Care (2010) 2010(14):R219. doi:10.1186/cc9348

37. Rivers E. Mixed versus central venous oxygen saturation may be not numerically equal, but both are still clinically useful. Chest (2006) 129:507-8. doi:10.1378/chest.129.3.507

38. van Beest PA, Wietasch G, Scheeren T. Clinical review: use of venous oxygen saturations as a goal - a yet unfinished puzzle. Crit Care (2011) 15:232. doi:10.1186/cc10351

39. Pope JV, Jones AE, Gaieski DF, Arnold RC, Trzeciak S, Shapiro NI, et al. EMShockNet. Multicenter study of central venous oxygen saturation (ScvO2) as a predictor of mortality in patients with sepsis. Ann Emerg Med (2010) 55:40-6. doi:10.1016/j.annemergmed.2009.08.014

40. Ince C, Sinaasappel M. Microcirculatory oxygenation and shunting in sepsis and shock. Crit Care Med (1999) 27:1369-77. doi:10.1097/00003246-19990700000031

41. Meregalli A, Oliveira RP, Friedman G. Occult hypoperfusion is associated with increased mortality in hemodynamically stable, high-risk, surgical patients. Crit Care (2004) 8:R60-5. doi:10.1186/cc2527

42. Nguyen HB, Rivers EP, Knoblich BP, Jacobsen G, Muzzin A, Ressler JA, et al. Early lactate clearance is associated with improved outcome in severe sepsis and septic shock. Crit Care Med (2004) 32:1637-42. doi:10.1097/01.CCM.0000132904. 35713.A7

43. Jansen TC, van Bommel J, Schoonderbeek FJ, Sleeswijk Visser SJ, van der Klooster JM, Lima AP, et al. Early lactate-guided therapy in intensive care unit patients: a multicenter, open-label, randomized controlled trial. Am J Respir Crit Care Med (2010) 182:752-61. doi:10.1164/rccm.200912-1918OC

44. Kruse JA, Zaidi SA, Carlson RW. Significance of blood lactate levels in critically ill patients with liver disease. Am J Med (1987) 83:77-82. doi:10.1016/00029343(87)90500-6

45. Orringer CE, Eustace JC, Wunsch CD, Gardner LB. Natural history of lactic acidosis after grand-mal seizures. A model for the study of an aniongap acidosis not associated with hyperkalemia. N Engl J Med (1977) 297:796. doi:10.1056/NEJM197710132971502

46. Nemeth M, Tanczos K, Demeter G, Erces D, Kaszaki J, Mikor A, et al. Central venous oxygen saturation and carbon dioxide-gap as resuscitation targets in a hemorrhagic shock. Acta Anaesthesiol Scand (2014). doi:10.1111/aas.12312

Conflict of Interest Statement: The authors declare that the research was conducted in the absence of any commercial or financial relationships that could be construed as a potential conflict of interest.

Received: 29 January 2014; accepted: 01 April 2014; published online: 30 April 2014. Citation: Tánczos K, Németh M and Molnár Z (2014) The multimodal concept of hemodynamic stabilization. Front. Public Health 2:34. doi: 10.3389/fpubh.2014.00034 This article was submitted to Infectious Diseases, a section of the journal Frontiers in Public Health.

Copyright (C) 2014 Tánczos, Németh and Molnár. This is an open-access article distributed under the terms of the Creative Commons Attribution License (CC BY). The use, distribution or reproduction in other forums is permitted, provided the original author(s) or licensor are credited and that the original publication in this journal is cited, in accordance with accepted academic practice. No use, distribution or reproduction is permitted which does not comply with these terms. 